УДК 811.161 .1 '42

DOI https://doi.org/10.26661/2414-9594-2021-1-6

\title{
МОВНА РЕПРЕЗЕНТАЦІЯ ХУДОЖНЬОГО КОНЦЕПТУ «МУЗИКА» В РОМАНІ Є. ВОДОЛАЗКІНА «БРІСБЕН»
}

\author{
Габідулліна А. Р. \\ доктор філологічних наук, \\ професор кафедри мовознавства та російської мови \\ Горлівський інститут іноземних мов \\ Донбаського державного педагогічного університету \\ вул. Василя Першина, 24, Бахмут, Донещька область, Україна \\ orcid.org/0000-0002-4271-4103 \\ allagabidullina54@gmail.com
}

\begin{abstract}
Ключові слова: поліфонія, світова музика, людська музика, інструментальна музика, ідіостиль.
\end{abstract}

Роман С. Водолазкіна «Брісбен» про музику, ії божественну природу, про ту силу, яка надає життю певний сенс і допомагає подолати негаразди. Метою дослідження є демонстрація мовних особливостей реалізації художнього концепту «музика» в романі С. Водолазкіна «Брісбен» відповідно до творчого замислу митця. Основним методом дослідження є дискурс-аналіз. Роман має форму канону - музичної форми, що грунтується напослідовності однієї й тієї ж мелодії в усіх голосах поліфонічого твору. Він пронизаний музикою, а його структура визначається музичними законами.

Відповідно до законів сольфеджіо, розповідь розпадається на два голоси: Гліба (щоденник) і Нестора - особистого бібліографа музиканта.

Загальна концепція музики (гармонії) в романі має три полюси, такі як світова музика (musica mundana), людська (musica humana) та інструментальна (musica instrumentalis). Іншими словами, розрізняють музику, створену й не створену людиною. Musica mundana гармонійна, вона відображає Божественний порядок, установлений у світобудові. «Людька музика» - це гармонія душі і тіла. Musica instrumentalis - це вокальне чи інструментальне звучання, земне втілення того, що народжене зверху, адже воно має відтворювати чи моделювати «світову» та «людську» музику.

Ядро текстового концепту в романі «Брісбен» відображає таку ідею твору: головне для справжнього художника - безсмертна душа, що з'єднує його з Богом. Усе інше (успіх, кар'єра, матеріальне благополуччя тощо) вторинне, оскільки є результатом того, що приходить зверху. Musica mundana експлікується в романі через поняття часу, вічності та смерті/безсмертя. Musica humana - лише часткове втілення ідеальної музики на землі. Периферія художнього концепту включає лексеми, що відображають види мистецтва, пов'язані з музикою; роди й види музики; жанри й напрями музичних творів; музичні інструменти; метафоричне позначення дій, де музика є суб'єктом; номінацію нот. Іншими словами, периферія поля співвідноситься з musica instrumentalis.

Максимально багатий ідіостиль Є. Водолазкіна, представлений різноманіттям способів вираження, може стати об'єктом подальших лінгвістичних досліджень. 


\title{
LANGUAGE REPRESENTATION OF THE ARTISTIC CONCEPT "MUSIC" IN THE NOVEL "BRISBANE" BY E. VODOLAZKIN
}

\author{
Gabidullina A. R. \\ Doctor of Sciences in Philology, \\ Professor at the Department of Linguistics and Russian Language \\ Gorlovka Institute of Foreign Languages \\ of Donbass State Pedagogical University \\ Vasil Pershyn str., 24, Bakhmut, Donetsk region, Ukraine \\ orcid.org/0000-0002-4271-4103 \\ allagabidullina54@gmail.com
}

Key words: polyphony, world music, human music, instrumental music, idiostyle.
E. Vodolazkin's novel "Brisbane" is about music, its divine nature, about the power that gives life a certain meaning and helps to overcome adversity. The purpose of the study is to show the linguistic features of the implementation of the artistic concept "music" in accordance with the creative intention of the writer. The main method is discourse analysis.

The novel is written in the canon style. It is saturated with music, and its structure is determined by musical laws. This is a polyphonic text that splits into two voices: Gleb (diary) and Nestor, the musician's personal bibliographer. The general concept of music (harmony) in the novel has three pillars. Musica mundane (world music) is harmonious; it reflects the Divine order established in the universe. "Human Music" is the harmony of body and soul. Musica instrumentalis is a vocal or instrumental sound, an earthly embodiment of what is born again: it should reproduce or simulate "world" and "human" music.

The core of the textual concept in the novel "Brisbane" reflects the main idea of the work: the main thing for a real artist is an immortal soul that connects him with God. The soul is associated with world music, which in the novel is called the prototype of music, heavenly eidos, and ideal music. Musica mundana is explicated in the novel through the concepts of time, eternity and death/immortality.

Musica humana is only a partial embodiment of ideal music on earth. Its nominations fill the near-nuclear zone of the artistic concept and include a) human actions that produce music (sing, play, perform, etc.); b) actions related to the manner of performing a piece of music, with elements and expressive means of music (three grace notes in a row, sixth chord, pizzicato and many others); the musical form used by composers and performers, c) with the effect produced by the music on the listener; d) nominations for the subject which is creating, performing or perceiving music.

The periphery of the artistic concept includes lexemes reflecting a) types of art associated with music; genera and types of music; b) genres and directions of musical works; c) musical instruments; d) metaphorical designation of actions, where music is the subject; e) the nomination of notes - in other words, the periphery of the field is related to musica instrumentalis.
Постановка проблеми. Євгеній Германович Водолазкін - сучасний письменник і вчений, випускник філологічного факультету Київського державного університету ім. Т. Шевченка (1986 рік). Його романи «Викрадення Європи», «Соловйов і Ларіонов», «Лавр», «Авіатор» тощо перекладені багатьма іноземними мовами. Роман «Брісбен» про музику, іiі божественну природу, про ту силу, що надає життю певного смислу й допомагає перебороти перешкоди. Багата, насичена музичною лексикою мова цього твору допомагає читачеві проникнути у творчу лабораторію геніального музиканта Гліба Яновського.

Аналіз публікацій. Художній концепт «музика» не раз ставав предметом дослідження в лінгвістичній літературі останнього десятиліття. Можна назвати роботи Т. Білотас [1], О. Спішевої [2], Л. Заболотської [3], Т. Загорської, В. Дружиніної 
[4], Н. Зіховської, В. Матвєйчук [5], Л. Коробко [6], А. Клокової [7], В. Саприкіної [8], у яких окреслено мовні особливості реалізації музичного концепту у творах письменників XIX - XX століть. Роман Є. Водолазкіна «Брісбен» теж став об' єктом дослідження в тезах О. Арзямової і М. Слинько «Концепт «музика» в романі Є. Водолазкіна «Брісбен»»» [9]. Автори проаналізували структурну організацію концепту в романі, провели статистичний аналіз лексико-семантичного поля, скрупульозно підрахувавши кількість лексем, пов'язаних із музикою, але не показали взаємозв'язок між вибором слова та ідейним замислом письменника.

Мета дослідження полягає в демонстрації мовних особливостей реалізації художнього концепту «музика» в романі Є. Водолазкіна «Брісбен» відповідно до творчого замислу митця.

Виклад основного матеріалу. Головний герой твору, всесвітньо відомий гітарист-віртуоз Гліб Яновський, на піку слави дізнається про смертельну недугу. Хвороба Паркінсона поступово позбавляє його можливості вести активну концертну діяльність. Гітарист-віртуоз, намагаючись повернути у своє існування гармонію, думає про сутність музики, розмірковує про смисл свого життя в трагічний період, коли зникає творча енергія. Для цього він занурюється в минуле, намагаючись зібрати воєдино спогади про київське дитинство сімдесятих років, юність у Ленінграді, сьогодення в Мюнхені і знову в Києві вже у двохтисячних.

Роман має форму канону - музичної форми, що грунтується на послідовності однієї і тієї ж мелодії в усіх голосах поліфонічого твору. Він пронизаний музикою, а його структура визначається музичними законами.

Перед нами поліфонічний текст. Відповідно до законів сольфеджіо, розповідь розпадається на два голоси: Гліба (щоденник) і Нестора - особистого бібліографа музиканта. Вони утворюють «стилістичний діапазон у три октави - від піднесеного пафосу й героїки до м'якої іронії» [10]. Перший голос, як це прийнято в епістолярних жанрах, простий, сповідальний. Він говорить про теперішне (2012-2014 роки, коли герой дізнається про свою невиліковну хворобу). Другий - це голос професійного письменника, «наспівувальний», ліричний та іронічний водночас. Він заглиблює читача в дитинство та юність Гліба. Минуле й теперішне чергуються, утворюючи хронотоп, що протікає в романі 3 різною швидкістю. Гліб - музикант за покликом душі і філолог за освітою - вільно говорить слов'янськими й германськими мовами, що переплітаються в його свідомості і звучать як музика. Цю особливість він помічає, будучи тьютором у богословському колегіумі святого Фоми в Німеччині: «Параллельные уроки музыки и языка поразили Глеба своим сходством <... Главное же состояло в том, что музыка была языком, а язык - музыкой». Етимологічно слово «мусике» означає «пов'язане з Музами» і стосується не тільки музики, але й словесної творчості (див. трактат Августина про віршування і віршовані стопи "De musica libri sex"). Мусичне - це те, що облаштоване гармонійно. Манеру гри Гліба на гітарі з голосовим супровідом («гудінням») критики називають надмелодією і порівнюють ії 3 «надтекстом Дюсойса чи Пруста, маючи на увазі додатковий смисл, щзо формується при читанні їхніх текстів. Він не зводиться до суми слів $i$ їх опису. Надтекст говорить про щуось таке, що основному тексту було не під силу».

Загальна концепція музики (гармонії) в романі має три полюси (за Боецієм) [11], такі як світова музика (musica mundana), людська (musica humana) та інструментальна (musica instrumentalis). Іншими словами, розрізняють музику, створену й не створену людиною. Musica mundana гармонійна, вона відображає Божественний порядок, установлений у світобудові. «Людька музика» - це гармонія душі і тіла. Musica instrumentalis - це вокальне чи інструментальне звучання, земне втілення того, що народжене зверху: воно має відтворювати чи моделювати «світову» та «людську» музику.

Отже, художній (авторський, текстовий) концепт «музика» в романі «Брісбен» виходить далеко за межі сучасних словникових значень та їх метонімічних варіацій: «1) мистецтво, що відображає дійсність у звукових художніх образах; інструментальний різновид такого мистецтва; сукупність таких творів; 2) перен. мелодійне звучання чого-небудь; 3) розм.-зниж. оркестр, музичний інструмент чи звуковідтворювальний прилад» [12]. Він складається з декількох зон, одна 3 яких включає об'єктивне, стійке уявлення соціуму про предмет чи явище (культурний концепт), а інші являють собою сукупність індивідуальних уподобань і асоціацій письменника. Результатом авторського бачення об'єкта стають численні смислові трансформації, як наслідок, культурний концепт розширюється і стає художнім. Іншими словами, у ньому «зливаються воєдино індивідуальноавторське розуміння і традиція національного вживання» [13, с. 22]. Межі полів культурного та індивідуально-авторського концептів у романі не збігаються. Те, що є ядром поля культурного концепту, знаходиться в близькоядерній зоні чи на периферії художнього. Усе залежить від позиції письменника.

Ядро текстового концепту в романі «Брісбен» відображає таку ідею твору: головне для справжньогохудожника-безсмертнадуша,щоз'єднуєйого з Богом. Усе інше (успіх, кар'єра, матеріальне благополуччя тощо) вторинне, оскільки є результатом 
того, що приходить зверху. Дід Мефодій, який привів внука до Господа, турбується не про його пальці, а про безсмертну душу: «Грають не рукою - душею». Думка не нова, але вона отримує в романі цікаве втілення.

Душа пов'язана зі світовою музикою, що названа в романі прообразом музики, небесним ейдосом, ідеальною музикою, іншими словами, Божим промислом про людину, яка може за певних умов перерости у творчу особистість чи залишитися нерозкритою. «Зрозуміло, що в кожного <..> існує відстань між цим промислом і тим, що насправді вийшло. $С$ така відстань і в Гліба, але $<\ldots>$ він до цього промислу достатньо близький» [14]. В останній період свого життя геніальний гітарист доходить висновку, що його хвороба - це не трагедія, а можливість наблизитися до Господа, пізнати те, що лежить за межею таланту.

Musica mundana експлікується в романі через поняття часу, вічності і смерті/безсмертя: «Музыла - это вечность, спросил Глеб. Отец Петр покачал головой: музыка - это не вечность. Но она напоминает о вечности - глубокая музыка. Что же такое вечность, спросил Глеб. Это отсутствие времени, предположил Мефодий, а значит, отсутствие смерти. В конечном счете, это Бог, сказал отец Петр». Роман закінчується парадоксальним, на перший погляд, висловлюванням знаменитого диригента, iз яким відбувся (чи не відбувся) останній концерт Яновського: «Идеальная музыка - это молчание». Прекрасна антитеза! Схожу думку ми зустрічаємо у Стінга, який вважає, що ідеальна музика - «це тиша, а музиканти займаються створенням красивого обрамлення навколо цієї досконалості» [15].

Musica humana - лише часткове втілення ідеальної музики на землі. Її номінації заповнюють близькоядерну зону художнього концепту і включають назви дій людини зі створення музики (nemb, играть, исполнять тощо: «Играли не пальцьь - вся сущиность Глеба <..> Исполнитель без остатка растворялся в музыке); найменування дій, пов'язаних із манерою виконання музичного твору, 3 елементами й засобами виразності в музиці (три форшлага подряд, секстаккорд, пищцикато тощо), з музичною формою, що їі використовують композитори та виконавці; назви, що стосуються ефекту, який справляє музика на слухача. Сюди ж відносимо номінації суб'єкта, який створює, виконує і сприймає музику.

Секрет успіху Гліба полягає в тому, що під час кожного нового виконання він грає твір наче вперше, заново відкриваючи, здавалося б, знайому музику для себе і слухачів та наповнюючи іiі власною енергією.

Основна прикмета музичного стилю головного героя - «гудіння» під час гри на гітарі: «Это гудение было как прообраз музыки, как ее небесный эйдос. Он не предшествовал музыке и не рождался ею, а точнее - и предшествовал, и рождался, поскольку совершенно не зависел от времени». Воно викликає асоціації з манерою Гленна Гульда - геніального канадського піаніста, органіста і композитора, який мав звичку щось мимрити або наспівувати собі під ніс під час виконання. Ще одна особливість гри Гліба - тремоло як «багатократне швидке повторювання одного звука чи швидке чергування двох несусідніх звуків, двох співзвучностей (інтервалів, акордів), окремого звуку чи співзвуччя» [16].

Ефект, який справляє музика на слухача, зазвичай позначається емоційно-експресивною та оцінною лексикою. Так, у композиції Яновського, де «на фоне иума воды звучит гитара», слухачі вловлюють відчай. В іншому музичному творі висота «звука переходит в высоту страдания. Утончается до полной несльишимости, потому что у горя нет выражения». Основний засіб позначення емоцій - метонімія і метафтонімія: «Не ожидая тишины, начинаю играть белорусскую Кувпалинку. <..>. На последней ноте поднимаю глаза и смотрю в зал. Вижу, как в отраженном от сиены свете блестят мокрые щеки. $<$...>. Когда Липу вековую я исполняю с голосовым сопровождением, зал тоже встает. <..>. Играя Ніч яка місячна, с болью сердечной наблюдаю, как босиком по холодной росе аудитория Карнеги-холла бредет в неизвестном направлении». Нерідко використовуються метафора і гіпербола: «Вспьхивающие в партере искры собираются в полноценную шаровую молнию <...> сияющций сгусток электричества проплывает над залом».

Номінатами суб'єктів, які створюють, грають і слухають музику, постають композитори, виконавці та слухачі. Про останніх йшлося раніше. Так, вони позначаються метонімічно: «аудиторія - люди, які заповнили аудиторію» (цим підкреслюється суперпопулярність музиканта, який грає виключно на світових майданчиках типу Карнегі-холу). Композитори поділяються в романі на «інтелектуалів» і тих, хто «испускает мощчные волны, накрывающие с головой». Серед других - Ремо Джадзотто, автор геніального твору («Адажіо»), який він приписав Альбіоні. Саме ці композитори, на думку Гліба, наближують «людську» музику до «світової, божественної». Виконавці - однокласники Гліба по музичній школі - домристи, його кохана віолончелістка Анна, Івасик-квартет (акордеон, скрипка, гітара й контрабас). Названі імена знаменитих гітаристів: Таррега, Джуліані, Сора.

Периферія художнього концепту включає лексеми, що відтворюють види мистецтва, пов'язані з музикою; роди та види музики; жанри й напрями музичних творів; музичні інструменти; 
метафоричне позначення дій, де музика є суб' єктом (Десять первых и самых знаменитых нот Токкаты взвиваются над оркестром, как тропический, вырастающий в течение ночи иветок); номінацію нот. Іншими словами, периферія поля співвідноситься 3 musica instrumentalis.

Гліб Яновський - різноплановий виконавець, який грає на гітарі як світську (переважно), так і духовну музику. Вона метонімічно позначається через імена композиторів i/чи назви їх творів: Дебюссі, Стравінський, Шнітке (більше ніж 20 авторів), з одного боку, “Ave Maria” Шуберта, фуги Баха, з іншого боку. За засобами виконання музика Гліба $\epsilon$ вокально-інструментальною: гра на гітарі супроводжується голосом. У романі описана театральна, симфонічна, камерна музика. Перша стає поштовхом до майбутньої музичної кар'єри героя роману. Так, постановка «Євгенія Онєгіна» в Київському оперному театрі справляє на дитину незабутнє враження: після першого помаху диригентської палички хлопчик «зарыдал-от этой гармонии, от неслыханной прежде полноты и силье звучания». Дорослий Гліб грає і соло, і у складі Івасик-квартету, і в дуеті з прийомною донькою Вірою, і з оркестром.

Талановитому гітаристу підкорилися багато напрямів (народна, духовна, академічна, популярна музика) і жанрів: на концертах Гліба вони перемежовуються і створюють єдиний емоційний простір. Українські народні пісні Яновський вважає «сказочно красивылии». У романі названі лише деякі жанри, які (окрім численних пісень) любить виконувати на гітарі герой твору: Концерт соль-мажор Вівальді, n'єса Сен-Санса «Лебідь» із сюїти «Карнавал тварин», Фуга ре мінор і Токката I. Баха, Реквісм Моиарта, Адажіо Альбіоні, Ноктюрн Шопена, хачатурянівський Вальс із «Маскараду», «Турецький марш» Моцарта.

Велику групу утворюють найменування музичних інструментів: фортепіано, рояль, клавесин, віолончель, арфа, контрабас, скрипка, акордеон, тарілки, барабан. На них грають усі музиканти, хто складає оточення головного героя. Його ж улюбленими інструментами є домра і гітара. Їх зображення в романі супроводжується великою кількістю порівнянь. Так, домра нагадує Глібу «улитку с вытянутой шеей» чи «цирокобедрую красавииу, принесенную не из музыкальной школь, а с клад- бища». Така асоціація виникає через футляр, схожий на труну. У гітарі музикант-підліток теж знаходить жіночі форми. Медіатор Гліб сприймає як продовження своєї руки, щось «вроде пластмассового ногтя, росшего из большого и указательного пальиа одновременно». Гра на домрі зазвичай готує учнів музичної школи до освоєння гітари, і ця сходинка на шляху до іншого інструмента характеризується батьком Гліба, Федором, за допомогою біблійної алюзії: «Зараз, синку, ти праџюєє сім років за Лію, а потім працюватимеш сім років за Рахіль. Игре на народных инструментах обучали пять лет, но библейская параллель отиа Глебу была понятна». Ця алюзія повториться в романі ще раз: дружина Гліба безплідна і мріє про те, щоб дитину їм народила інша жінка.

Музичними інструментами стають для Яновського побутові предмети і навіть власний організм. Скрипіння газети під час миття вікон викликає в нього асоціації з грою на струнних інструментах. Вхідні двері мають свій діапазон: «от тихого щелканья язычка в замке <... до ураганного удара с сотрясением обеих створок». Миттєвий дотик до кнопки дзвінка - тявканье щенка, два короткі дзвінки - воздушное стаккато, два довгі «рождали мысль о бомбоубежище», звук інтенсивного дзвінка названо скандальнылм. Навіть викривлені зуби і пластини для вирівнювання прикусу стають музичними інструментами, адже за їх допомогою хлопчик виконує «Повітряну кукурудзу» Гершона Кінгслі. Звуки природи теж $є$ джерелом натхнення. Це може бути скрекіт коників, який посилюють цикади, адже вони нагадують Глібу «огромный, играющий в унисон оркестр. Апофеоз пиления, торжество смычковых. Предельная преданность музыке: инструментом является тело музыканта».

Висновки i перспективи дослідження. Ми (у зв'язку з обмеженим обсягом статті) назвали лише деякі лексико-стилістичні засоби мовної репрезентації концепту «музика» в романі Є. Водолазкіна «Брісбен». Усі вони спрямовані на вираження такої ідеї твору: головне для справжнього художника - безсмертна душа, яка з'єднує його $з$ Богом. Максимально багатий ідіостиль €. Водолазкіна, представлений різноманіттям способів вираження, може стати об'єктом подальших лінгвістичних досліджень.

\section{ЛІТЕРАТУРА}

1. Билотас Т. Концепт «музыка» в романе Л. Улицкой. Классика и современность : сборник научных трудов молодых ученых-филологов. Брест : БГУ, 2011. С. 18-22.

2. Епишева О. Музыка и музыканты в лирике К.Д. Бальмонта. Молодая наука в классическом универcumeme. 2006. Ч. 6 : Русская словесность: Текст и контекст. С. 4-5.

3. Заболотская Л. Отражение концепта «музыка» в повести Томаса Бернхарда «Племянник Витгенштейна». Вестник Московского государственного университета культуры и искусств. 2017. № 4 (78). C. 102-109. 
4. Загорская Т., Дружинина В. Концепт «музыка» в художественном дискурсе К.Г. Паустовского: к вопросу изучения. Филология и культурология: современные проблемы и перспективы развития : сборник материалов XX Международной научно-практической конференции. Сочи, 2016. С. 14-15.

5. Зыховская Н., Матвейчук В. Концепт «музыка» в романе Ч. Айтматова «Когда падают горы (Вечная невеста)». Челябинский гуманитарий. 2016. № 3 (36). С. 34-42.

6. Коробко Л. Общее и специфическое в вербальной экспликации концепта «музыка» в русской художественной картине мира XIX - XX вв. Современные лингвистические и методико-дидактические исследования. 2017. № 4 (36). С. 78-94.

7. Клокова А. Анализ художественного концепта (на материале концепта «музыка» в лирике К.Д. Бальмонта). Человек, текст, язык в системе социогуманитарного знания : сборник материалов II Всероссийской конференции. Нижний Тагил, 2018. С. 151-159.

8. Сапрыкина В. Национальная специфика языкового отражения концепта в художественной картине мира (на материале вербализации концепта «музыка» в русской и немецкой поэзии XIX - XX вв.) : автореф. дисс. ... канд. филол. наук : спец. 10.02.19 «Теория языка». Воронеж, 2005. 23 с.

9. Арзямова О., Спинько М. Концепт «музыка» в романе Е.Г. Водолазкина «Брисбен». Филологические открытия : сборник научных статей VII Международной научно-методической конференции. Уссурийск, 2019. С. 5-8.

10. Роман в три октавы: Галина Юзефович - о том, как устроен «Брисбен», самая музыкальная книга Евгения Водолазкина. URL: https://meduza.io/feature/2018/12/08/roman-v-tri-oktavy.

11. Холопов Ю., Поспелова Р. Философия гармонии Боэция. Гармония: проблемы науки и методики. 2005. Вып. 2. С. 38-66.

12. Ефремова Т. Новый словарь русского языка: толково-словообразовательный : в 2 т. Москва : Русский язык, 2001. Т. 1. 1084 с.

13. Красовская Н. Художественный концепт: методы и приемы исследования. Известия Саратовского университета. 2009. Т. 9. № 4. С. 21-25.

14. Каплан В. Жизнь как продолжение жизни: в чем смысл нового романа Водолазкина «Брисбен». Фома. URL: https://foma.ru/zhizn-kak-prodolzhenie-zhizni-v-chem-smyisl-novogo-romana-vodolazkina-brisben.html.

15. Жемчужины мысли. URL: https://www.inpearls.ru/221455.

16. Тремоло. Википедия. URL: https://ru.wikipedia.org/wiki/\%D0\%A2\%D1\%80\%D0\%B5\%D0\%BC\%D0 $\% \mathrm{BE} \% \mathrm{D} 0 \% \mathrm{BB} \% \mathrm{D} 0 \% \mathrm{BE}$.

\section{REFERENCES}

1. Bilotas T. (2011) Koncept "muzyka" v romane L. Ulickoj. [The Concept of "Music" in the Novel by L. Ulitskaya]. Klassika i sovremennost' [Classics and Modernity]: sb. nauch. trudov molodyh uchenyhfilologov. Brest : BGU, pp. 18-22. Collection of Research Papers of Young Philology-Scientists.

2. Episheva O. (2006) Muzyka i muzykanty v lirike K.D. Bal'monta. [Music and Musicians in the Lyrics of K.D. Balmont]. Molodaya nauka v klassicheskom universitete. Ivanovo, vol. 6. Russkaya slovesnost': Tekst i kontekst, pp. 4-5. [Young Science at a Classical University. Russian Philology. Text and Context].

3. Zabolotskaya L. (2017) Otrazhenie koncepta «muzyka» v povesti Tomasa Bernharda "Plemyannik Vitgenshtejna". [Reflection of the Concept of "Music" in the story of Thomas Bernhard "Wittgenstein's Nephew"]. Vestnik Moskovskogo gosudarstvennogo universiteta kul tury i iskusstv [Bulletin of Moscow State University of Culture and Arts], no. 4 (78), pp. 102-109.

4. Zagorskaya T., Druzhinina V. (2016) Koncept "muzyka" v hudozhestvennom diskurse K.G. Paustovskogo : k voprosu izucheniya. [Concept "Music" in Artistic Discourse of K.G Paustovsky: to the Question of Studying]. Filologiya i kul'turologiya: sovremennye problemy i perspektivy razvitiya [Philological and Cultural Studies: Modern Problems and Prospects of Development] : sb. materialov $X X$ Mezhdunarodnoj nauchno-prakticheskoj konferencii (Sochi, 15.05.2016). Sochi, pp. 14-15 [Collection of Materials of the International Scientific and Practical Conference].

5. Zyhovskaya N., Matvejchuk V. (2016) Koncept "muzyka" v romane Ch. Ajtmatova "Kogda padayut gory (Vechnaya nevesta)". [The Concept of "Music" in the Novel by Ch. Aitmatov "When the Mountains are Falling (The Eternal Bride)"]. Chelyabinskij gumanitarij. Chelyabinsk, no. 3 (36), pp. 34-42.

6. Korobko L. (2017) Obshchee i specificheskoe v verbal'noj eksplikacii koncepta «muzyka» v russkoj hudozhestvennoj kartine mira XIX - XX vv. [General and Special in the Verbal Explication of the Concept "Music" in the Russian Artistic Picture of the World of the XIX - XX Centuries]. Sovremennye lingvisticheskie i metodiko-didakticheskie issledovaniya, no. 36, pp. 78-94.

7. Klokova A. (2018) Analiz hudozhestvennogo koncepta (na materiale koncepta "muzyka" v lirike K.D. Bal'monta). [Analysis of the Artistic Concept (Based on the Materials of the Concept "Music" in the 
Lyrics of K.D. Balmont)]. Chelovek, tekst, yazyk v sisteme sociogumanitarnogo znaniya [A Person, a Text, a Language in the System of Socio-Humanitarian Knowledge] : sb. materialov II Vserossijskoj konferencii (N. Tagil, 22.12.2018). N. Tagil, pp. 151-159. Collection of Materials of the II All-Russia Conference.

8. Saprykina V. (2005) Nacional'naya specifika yazykovogo otrazheniya koncepta v hudozhestvennoj kartine mira (na materiale verbalizacii koncepta "muzyka" v russkoj i nemeckoj poezii XIX - XX vv) [National Specifics of the Linguistic Representation of a Concept in the Artistic Picture of the World (Based on the Material of the Verbalization of the Concept "Music" in Russian and German Poetry of the XIX $\mathrm{XX}$ centuries)]. (PhD Thesis). Voronezh, voronezhskiy gosudarstvennyiy universitet, $23 \mathrm{p}$.

9. Arzyamova O., Spin'ko M. (2019) Koncept "muzyka" v romane E.G. Vodolazkina "Brisben". [The Concept of "Music" in the Novel by E.G. Vodolazkin "Brisbane"]. Filologicheskie otkrytiya : sb. nauchnyh statej VII Mezhdunarodnoj nauchno-metodicheskoj konferencii. Ussurijsk, 2019, pp. 5-8. [Philological Discoveries: Collection of Scientific Articles of VII International Scientific and Methodological Conference].

10. Roman v tri oktavy: Galina Yuzefovich o tom, kak ustroen "Brisben", samaya muzykal'naya kniga Evgeniya Vodolazkina. [A Novel in Three Octaves: Galina Yuzefovich about how "Brisbane" is arranged, the most musical book by Evgeny Vodolazkin]. URL: https://meduza.io/feature/2018/12/08/roman-v-tri-oktavy.

11. Holopov Y., Pospelova R. (2005) Filosofiya garmonii Boeciya. ) [Boethius‘ Philosophy of Harmony]. Garmoniya: problemy nauki i metodiki. 2005. Vyp. 2, pp. 38-66.

12. Efremova T. (2001) Novyj slovar' russkogo yazyka : tolkovo-slovoobrazovatel'nyj. [The New Dictionary of the Russian Language: Explanatory and Word-Formation]. V 2 t. M. : Russkij yazyk, 2001. T. 1. 1084 p. Russian Language.

13. Krasovskaya N. (2009) Hudozhestvennyj koncept : metody i priemy issledovaniya. [Artistic Concept: Methods and Techniques of Research]. Izvestiya Saratovskogo universiteta. Saratov: SGU, vol. 9, no. 4. pp. 21-25. News of the Saratov University.

14. Kaplan V. Zhizn' kak prodolzhenie zhizni: v chem smysl novogo romana Vodolazkina "Brisben". [Life as a Continuation of Life: What is the Meaning of the Novel "Brisbane" by Roman Vodolazkin]. Foma . URL : https://foma.ru/zhizn-kak-prodolzhenie-zhizni-v-chem-smyisl-novogo-romana-vodolazkina-brisben.html Foma: Orthodox Journal.

15. Zhemchuzhiny mysli [Pearls of Thought]. URL: https://www.inpearls.ru/221455.

16. Tremolo. Vikipediya. URL: https://ru.wikipedia.org/wiki/\%D0\%A2\%D1\%80\%D0\%B5\%D0\%BC\%D0\% $\mathrm{BE} \% \mathrm{D} 0 \% \mathrm{BB} \% \mathrm{D} 0 \% \mathrm{BE}$. 